\title{
KUIDAS EESTI KEELE ÕPPIJAD JA KASUTAJAD LAUSE VERBI AJAVORMI SOBIVUST HINDAVAD?
}

\section{Diana Maisla}

Ülevaade. Verbi ajavormide kasutamine on üks grammatika valdkondadest, mis pakub jätkuvalt huvi teise keele omandamise uurijatele. Artiklis on vaatluse all grammatilise sobivuse hindamise testi tulemused, milles võrreldakse 96 vene ja 100 eesti emakeelega üliõpilase valikuid ülesandes, kus tuli hinnata oleviku ja kolme mineviku ajavormi sobivust eestikeelsesse lausesse skaalal sobib täpselt / sobib samuti / ei sobi. Kogutud andmeid on töödeldud SPSS-programmi abil ning statistiliste testide tulemuste põhjal selgitatud välja erinevused keelejuhtide rühmade vahel. Olulised erinevused kahe rühma vahel ilmnesid täis- ja enneminevikulise verbi sobivusele antud hinnangute vahel, kuid oleviku ja lihtmineviku sobivust on vene keelejuhid hinnanud eesti keelejuhtidega suhteliselt sarnaselt.

Ajavormi sobivusele antud hinnanguid põhjendas 28 eesti ja 29 vene keelejuhti. Põhjenduste ja tegelike valikute järgi saab teha järeldusi nii vene kui ka eesti keelejuhtide teadmiste ja arusaamiste kohta ajavormide kasutamisest. Eesti keelejuhtide põhjendustest selgub, et liht- ja enneminevikku peetakse ajavormideks, mis väljendavad minevikus toimunud tegevusi. Täisminevikku tajutakse tugevalt olevikuga seotud ajavormina. Vene keelejuhid eristavad olevikku ja lihtminevikku, s.t oskavad hinnata nende sobivust lausesse ning seda hinnangut ka põhjendada. Erinevalt eestlastest täismineviku ajavormi seotust olevikuajaga ei mõisteta, see seostub vene keelejuhtidele faktide konstateerimise, tegevuse korduvuse, lõpetatusega ja jätkuvusega. Ennemineviku ajavormi sobivust või mittesobivust lausesse on eesti keelejuhid hinnanud väga üksmeelselt, kuid suurel osal vene keelejuhtidest tundub selle ajavormi kasutamise suhtes olevat suuri kõhklusi, pigem eelistatakse kasutada lihtmineviku ajavormi.

Võtmesõnad: eesti keel kui teine keel, ajavormid, grammatilise sobivuse hindamine, introspektsioon, eesti keel 


\section{Sissejuhatus}

Eesti verbi kasutuse uuringute põhjal on tähelepanu juhitud sellele, et keel lihtsustub ja mineviku liitajavormide asemele asub kohati lihtminevik (vt nt Erelt 2006, Metslang 2006). Seda on peetud nii keeles toimuvate nihete (Metslang 1991: 166, 1993: 213) kui vene keele mõju (vt nt Saari 2004: 368, 593-594, Leemets 2000: 87-90) tagajärjeks. Eesti keelt teise keelena kõnelevate venelaste puhul võivad kõik minevikuvormid olla üldistunud lihtmineviku ajavormiks vene emakeele interferentsi tõttu (Pool, Vaimann 2005: 134). Vene keeles väljendatakse selliseid ajasuhteid, milleks eesti keel vajab liitajavorme, aspektikategooria abil (Külmoja jt 2003: 84, Külmoja 2007: 80-81).

Niisiis on huvipakkuv, millised tegurid mõjutavad keelekasutajat eestikeelse lause verbi ajavormi valima. Sellele küsimusele oskavad tõenäoliselt vähemalt osaliselt vastata need, kes selle valiku teinud on. Eesmärk oli uurida, milliseid verbi ajavorme eestikeelsetel õppekavadel õppivad eesti ja vene emakeelega üliõpilased lausesse sobivaks peavad ning kuidas nad oma valikuid põhjendavad. Kuigi peamiselt on huvi keskmes mineviku liitajavormid, ei ole kõrvale jäetud ka olevikku ega lihtminevikku.

Keel on suhtlusvahend ja selle õppimiseks on suhtlus õpitavas keeles väga tähtis. Sujuv suhtlus eeldab head keelekasutust, millest lisaks sõnaseadmisoskusele moodustab olulise osa grammatiline korrektsus. Grammatiliselt korrektne keelekasutus on edasijõudnud õppija ideaal ja siht, mille poole püüelda. Teatud vastuolu seisneb selles, et grammatika on kirjeldatud normatiivsete reeglitena, millest tegelik keelekasutus võib erineda. Siinne artikkel annab ülevaate eesti ja vene keelejuhtide sooritatud keeleülesande tulemustest, millest peaks selguma, kui hästi vene keelejuhid eesti verbi ajavormide kasutust mõistavad. Lähtekohaks on võetud see, et vene keelejuhtide grammatilise õigsuse hinnanguid tuleb kõrvutada eesti keelejuhtide grammatiliste vormide tegeliku kasutusega, mitte keelekäsiraamatute reeglitega. Tegelikus keelekasutuses ilmnev ajavormikasutus on keerulisem ja mitmekesisem kui on suudetud akadeemiliselt reeglistada. Niisiis ei ole uuritud, milliste reeglite vastu vene üliõpilased eksivad, vaid kuivõrd nende hinnangud ajavormi kasutuse kohta eesti üliõpilaste hinnangutega sarnanevad ja mille poolest erinevad.

\section{Keelejuhid ja andmekogumismeetod}

Keelejuhtidele anti viis tekstilõiku, mille ühte lausesse oli jäetud lünk. Iga lünga juurde kuulus tabel, millesse tuli teha märge selle kohta, kas olevikus, liht-, täis- ja enneminevikus verb on lausesse täpselt sobiv, samuti sobiv või mittesobiv. Pärast valiku tegemist pidid vastajad oma valikut põhjendama. Tööjuhendis oli öeldud, et kui põhjendust kirjutada ei oska, siis võib vastava rea tühjaks jätta. Selline mööndus oli vajalik, sest esmane eesmärk oli saada keelejuhtidelt teavet, millist ajavormi nad lausesse sobivaks peavad. Hinnangu põhjendamine oli samuti oluline, kuid mitte peamine. Lõigud olid valitud nii, et esindatud oleks nii olevikulised kui ka minevikulised laused. Algsetes ajaveebidest ja foorumitest võetud variantides oli kasutatud täisminevikku (II, IV ja V lõigus) ning enneminevikku (I ja III lõigus). 
Ülesande koostamisel on arvesse võetud varasemaid introspektsiooni uuringuid (Ellis, Barkhuzein 2006: 45-46, Ellis 2008: 10-12, Mackey, Gass 2005: 50-51), mille põhjal on nimetatud meetod liigitatud kolmeks eri tüübiks: 1) keelejuht teeb mina-aruande, milles hindab oma tegevust küsitluse või hinnanguskaala järgi; 2) keelejuht mõtleb valjult, s.t ülesande sooritamise ajal jutustab, mida ta parajasti teeb; 3) keelejuht kommenteerib pärast ülesande sooritamist, kuidas ta otsuseid vastu võttis ja miks ta just selliseid vastuseid andis. Varasematest uuringutest on teada, et keelejuhid ei pruugi alati osata oma keelelise käitumise põhjusi selgitada. Grammatikaoskus ja reeglite teadmine võib olla alateadlik ehk teadvustamata, mistõttu keelekasutaja ei suuda seda sõnastada. Sel juhul ei saa introspektsiooni abil öelda, et teatakse või tunnetatakse või kasutatakse teatud grammatikareegleid või põhimõtteid, sest nendele reeglitele ja põhimõtetele ei ole ligipääsu (Chomsky 1980: 128, 237). Introspektsiooni kui meetodi kriitikud märgivad, et uuritav võib kirjeldada teadmist või tegevust või kavatsust või kõiki kolme aspekti; ning et kui antakse teavet lühimälu töö kohta, siis ei saa selle põhjal teha järeldusi püsimälus säilivate teadmiste kohta (ülevaadet eri uurimustest vt nt Macaro 2006 või Seliger, Shohamy 1989: 170). Vaatamata eelmainitule oskab haritud keeleõppija oma tegevuse põhjusi kui mitte keeleteaduse termineis, siis vähemalt oma sõnadega kirjeldada.

Introspektsiooni on eelkõige kirjeldatud kui suulist andmete kogumise meetodit, kuid päriselt ei välistata ka kirjalikku teabe kogumist vahetult pärast ülesande täitmist (Seliger, Shohamy 1989: 171). Meetodit on peamiselt kasutatud selleks, et kindlaks teha õpistrateegiaid, mis peaksid andma õpetajatele kasulikku teavet õpiprotsessi paremaks korraldamiseks. Siiski sobib see ka keeleõppijate metalingvistiliste teadmiste uurimiseks (Birdsong 1989, Ellis 2005, Ellis, Barkhuzein 2006: 5-6). Eestis on introspektsiooni meetodit kasutanud Raili Pool (2006, 2007), kelle keelejuhid arutlesid selle üle, kuidas nad õigeks peetava grammatilise vormi leidsid, ja kirjeldasid ülesande tegemise käiku, s.o nii väljendasid metalingvistilisi teadmisi kui ka kirjeldasid kasutatud strateegiaid.

Ka siinses artiklis käsitletav ülesanne nõudis metalingvistiliste teadmiste kasutamist, millest verbi ajavormi sobivuse hindamine eeldab mõõdukat ja hinnangute põhjendamine väga kõrget analüüsioskust (Birdsong 1989: 35-36). Siiski ei eeldatud, et põhjendustes kasutatakse keeleteaduslikku sõnavara või viidatakse normatiivsetele reeglitele.

Keelejuhte oli kokku 196, neist 57 põhjendas oma hinnanguid. Põhjendajatest 28 olid eestlased, 29 venelased. Põhjendusi on esitatud ebaühtlaselt: osa põhjendustest on ühesõnalised, osa koosneb mitmest lausest; 13 keelejuhti on kirjutanud seletusi ainult ühe lause verbivormi valiku kohta, 23 keelejuhti on aga kommenteerinud kõigi viie lause kohta antud hinnanguid. Nende puhul, kes on kirjutanud põhjenduseks vähemalt ühe täislause kõigi viie verbi ajavormi valiku kohta, võib jälgida, milline arusaamine neil ajavormide kasutamisest on. Oma hinnanguid põhjendas järjekindlalt kaks eesti ja kolm vene keelejuhti. Nende mõttekäigud on esitatud 4. jaotises. Ühesõnalise põhjenduse ja/või ainult ühte või kahte valikut kommenteerinute arusaamiste kohta põhjalikumaid järeldusi teha ei saa, kuid nende vastused on üldises analüüsis arvesse võetud.

Valikute tulemustest on koostatud sagedustabelid. Nendes on andmed iga ajavormi valinute hulga kohta. Keelejuhtide hulk protsendina näitab, kui palju 
vastajatest on ajavormi pidanud lausesse täpselt sobivaks, samuti sobivaks ja mittesobivaks. Kuna igal vastajal oli võimalus hinnata kõikide ajavormide sobivust ja näiteks täpselt sobivaks võis märkida kasvõi kõik neli ajavormi, saab hinnata iga ajavormi kohta antud hinnanguid eraldi, kuid ühe ajavormi sobivaks märkimise korral ei saa eeldada, et mingi teine ajavorm on ebasobiv. Programmi SPSS abil on tehtud hii-ruut test, millega saab hinnata, kas kahe uuritava rühma ajavormi valikute vahel on statistiliselt olulisi erinevusi (olulisusnivoo $\alpha=0,05$ ) ning kui suur on hajuvus rühmade sees.

Analüüsi tulemused esitatakse nii allülesannete kaupa kui kahe rühma valikute lõikes. Põhjenduste analüüsimisel tuleb vaadata ka seda, millised valikud keelejuht on teinud. Iga keelejuht on märgitud numbriga ning kõik tema valikud on koondatud Exceli tabelisse. Niisugusel kujul saab eri keelejuhtide valikuid omavahel võrrelda ning kontrollida, kas keelejuhi valikud ja nende tegemise põhjendused on omavahel kooskõlas.

\section{3. Ülesande lahendamise tulemused}

Esimene lõik on esitatud siin sellisel kujul, nagu oli keelejuhtidele antud ülesanne. Järgmised neli ülesandelõiku on lihtsustatult: valikutabelist on loobutud ja valikuks pakutud verbivormid on teksti sees alla joonitud.

\subsection{Esimene Iõik}

Koolist saadeti meid teele tordi, kohvi ja parimate soovidega. Kinkisime omalt poolt mõned meened, mis me Eestist kaasa Jaamas jätsime hüvasti ja algas sõit koju tagasi.

\begin{tabular}{|l|l|l|l|}
\hline & täpselt sobiv & samuti sobiv & ei sobi \\
\hline toome & & & \\
\hline tõime & & & \\
\hline oleme toonud & & & \\
\hline olime toonud & & & \\
\hline
\end{tabular}

Tabel 1. Eesti ja vene keelejuhtide valikute tulemused protsentidena

\begin{tabular}{|l|c|c|c|c|c|c|}
\hline \multirow{2}{*}{ Esimene lõik } & \multicolumn{3}{|c|}{ Eesti keelejuhid } & \multicolumn{3}{c|}{ Vene keelejuhid } \\
\cline { 2 - 7 } & $\begin{array}{c}\text { täpselt } \\
\text { sobiv }\end{array}$ & $\begin{array}{c}\text { samuti } \\
\text { sobiv }\end{array}$ & ei sobi & $\begin{array}{c}\text { täpselt } \\
\text { sobiv }\end{array}$ & $\begin{array}{c}\text { samuti } \\
\text { sobiv }\end{array}$ & ei sobi \\
\hline olevik & - & - & $100 \%$ & - & $1 \%$ & $99 \%$ \\
lihtminevik & $37 \%$ & $52 \%$ & $11 \%$ & $40 \%$ & $42 \%$ & $17 \%$ \\
täisminevik & $2 \%$ & $15 \%$ & $83 \%$ & $26 \%$ & $29 \%$ & $45 \%$ \\
enneminevik & $73 \%$ & $19 \%$ & $7 \%$ & $42 \%$ & $38 \%$ & $20 \%$ \\
\hline
\end{tabular}


Tabelis esitatud tulemuste põhjal ei sobi lausesse oleviku ajavorm. Nii eesti kui vene keelejuhid on sellise valiku teinud täiesti üksmeelselt. Milline mineviku ajavorm kõige paremini sobib, selles lähevad kahe rühma valikud lahku. Eestlased peavad kõige sobivamaks enneminevikku: $73 \%$ vastajatest on seda täpselt sobivaks ja $19 \%$ samuti sobivaks pidanud. Sobivaks on peetud ka lihtminevikku, kuid täpselt sobivaks peab seda poole vähem, s.o $37 \%$ vastajatest. Täisminevikku on pidanud täpselt või samuti sobivaks kokku $17 \%$ vastajatest. Vene keelejuhid hindavad enneja lihtminevikku samavõrra sobivateks vormideks ( $42 \%$ ja $40 \%$ vastajatest) ning täisminevikku peab sobivaks $26 \%$ vastajatest. Kui $83 \%$ eesti keelejuhtidest peab täismineviku kasutamist mittesobivaks, siis vene keelejuhtidest on sama valiku teinud poole vähem, s.o $45 \%$ vastajatest. Samuti on vene vastajate hulgas suur hulk neid, kes kahtleb enne- ja lihtmineviku sobivuses (kokku 37\%). Statistiliselt ei ole rühmade vahel olulist erinevust oleviku $(\mathrm{p}=0,316)$ ja lihtmineviku $(\mathrm{p}=0,279)$ ajavormide sobivuse hindamisel.

Eestlaste valikute põhjendused saab jagada kolme rühma:

1) põhjendatakse sellega, et "nii tundub õige" (7 vastajat);

2) esitakse lühike kommentaar, näiteks "lause on minevikus" (8 vastajat);

3) seletatakse, kuidas lausest aru saadakse ja/või arutletakse pikemalt, miks üks või teine vorm sobib: "osad on valed ajavormid, sest tegevus toimus minevikus" või "eelnevalt olime meened ju Eestist kaasa võtnud". Väga kindlal seisukohal on vastaja, kes väidab, et "aeg peab lüngas olema enneminevik" ning kõik teised ajavormid ebasobivaks märkinud. Üks keelejuht põhjendab oma valikuid, et "lause on lihtminevikus, aga samuti võib kasutada ka täisminevikku. Tegevus on lõpetatud." Selles põhjenduses vastandatakse enneminevik liht- ja täisminevikule, sest ennemineviku on keelejuht mittesobivaks märkinud. Selline seisukoht on ainukordne, sest ükski teine keelejuht samasugust valikut teinud ei ole. Keelejuhi arusaam, et liht- ja täisminevik väljendavad lõpetatud tegevust, kuid enneminevik lõpetamata tegevust, saab kinnitust hiljem, kui võrrelda esimese ja kolmanda lõigu verbi ajavormi valiku põhjendust.

Niisiis tuuakse oma valikute põhjendustes esile keeletaju, lause teiste verbide ajavorm ning lause verbides väljenduvad tegevuste aja- ja aspektisuhted. Peamine argument enne- ja lihtmineviku valikuks on see, et lause on minevikus.

Vene keelejuhtide põhjendused võib samuti jagada rühmadesse:

1) lühikese kommentaari "lause on mineviku vormis" või "tegevus toimub minevikus" on kirjutanud 10 vastajat;

2) viidatakse lause sisu sellele aspektile, mis on aidanud valikut teha: "sest nad juba sõitsid ära ja on vaja minevikku"; "meened tõime ju enne, kui neid kinkisime. Seega üks minevik (kinkisime) oli varem kui teine minevik (kaasa tõime)" (7 vastajat);

3) demonstreeritakse ajavormide kasutuse kohta käivate reeglite tundmist (6 vastajat):

- ““Tõime” lópetamata tegevus. Ei tea, mis täpne tulemus on. Olime toonud (kui tõime ja jätsime sinna).” Keelejuht on valinud ennemineviku täpselt sobivaks ja lihtmineviku samuti sobivaks. Põhjenduse järgi võib otsustada, et ta peab enneminevikku kindlalt lõpetatud resultatiivse 
tegevuse väljendajaks, kuid lihtminevikku mitteresultatiivseks, kuigi samuti minevikus toimunud tegevuse väljendajaks;

- "Esimesena toimus meenete toomine ja alles siis - kinkimine. "Toomine" lihtminevik, "kinkimine" - täisminevik." Seda seletust on raske keelejuhi valikutega seostada ning need seletavad laused on ka teineteise suhtes vastuolulised. Valitud on täisminevik kui täpselt sobiv ja lihtminevik kui samuti sobiv;

- "Kui tahame rõhutada, et ka minevikus on eri aegadel tegevus toimunud (enneminevik), lihtminevik, kui seda rõhutust ei peeta oluliseks." Keelejuht on märkinud ennemineviku täpselt sobivaks ja lihtmineviku samuti sobivaks. Enneminevik on tema arvates tugevamini markeeritud ajavorm (rõhutab tegevuse toimumist minevikus) kui lihtminevik, mis on niisiis neutraalsem;

- "Laused on jutustuse vormis." Sellise põhjenduse on kirjutanud kaks keelejuhti. Õppekirjanduse põhjal on lihtminevik jutustuse ja täisminevik kirjelduse aeg. Üks keelejuhtidest ongi lihtmineviku täpselt sobivaks ning ennemineviku samuti sobivaks märkinud, kuid teine peab täpselt sobivaks täisminevikku ja samuti sobivaks lihtminevikku. Seega ei saa kindlalt väita, et mõlemad keelejuhid on lähtunud samast reeglist;

- üks keelejuht on põhjendanud oma valikut lause sõnajärjega: "Täis- ja enneminevik ei sobi, sest verb peab olema II kohal (SVO).” Ta peab ainsaks õigeks vormiks lihtminevikku ning välistab täis- ja ennemineviku, sest abiverb olema on ülesande lauses koos partitsiibiga osalause lõpul, mitte subjekti järel teisel kohal.

Lünka sobiva ajavormi valikutest ilmneb kõikide keelejuhtide otsus, et lause ei ole olevikus. Eestlaste hinnangute järgi õige ajavormi kohta võib väita, et eelistatakse kindlalt enneminevikku, kuid suur hulk vastajatest peab õigeks ka lihtminevikku. Täisminevikku peetakse pigem mittesobivaks. Vene keelejuhtide valikud nii selgelt ühe ajavormi kasuks ei jagune. Liht- ja enneminevikku peab sobivaks üsna ühesuurune hulk vastanutest, kuid täisminevikku peab sobivaks kokku üle poole vastanutest. Niisiis ei mõista ega taju vene keelejuhid täismineviku seotust olevikuga nii selgelt kui eesti keelejuhid.

Põhjendusi on vene keelejuhid kirjutanud mitmekülgsemalt kui eesti keelejuhid. Lisaks lause sisule ja lõigu verbide ajavormidele osutamisele on vene keelejuhid esile toonud ka lauseehituse reeglid ja eri ajavormide kasutamise funktsioonid.

\subsection{Teine lõik}

Elan Põlvamaal Värskas, mis on minu arvates üks ilusama loodusega kohti Eestis. Aga kui palju ma tegelikult oma kodukohast, seal elavatest loomadest ja kasvavatest taimedest tean? Ma ise arvan, et mitte piisavalt. Kõige rohkem käin / käisin / olen käinud / olin käinud looduses oma vanaema ja vanaisaga. Vanaema õpetas mulle juba siis, kui ma väike olin, et puud on elus ja kui on mõni mure, siis puud aitavad meid. 
Tabel 2. Eesti ja vene keelejuhtide valikute tulemused protsentidena

\begin{tabular}{|l|c|c|c|c|c|c|}
\hline \multirow{2}{*}{ Teine lõik } & \multicolumn{3}{|c|}{ Eesti keelejuhid } & \multicolumn{3}{c|}{ Vene keelejuhid } \\
\cline { 2 - 7 } & $\begin{array}{c}\text { täpselt } \\
\text { sobiv }\end{array}$ & $\begin{array}{c}\text { samuti } \\
\text { sobiv }\end{array}$ & ei sobi & $\begin{array}{c}\text { täpselt } \\
\text { sobiv }\end{array}$ & $\begin{array}{c}\text { samuti } \\
\text { sobiv }\end{array}$ & ei sobi \\
\hline olevik & $22 \%$ & $36 \%$ & $41 \%$ & $19 \%$ & $16 \%$ & $65 \%$ \\
lihtminevik & $29 \%$ & $43 \%$ & $27 \%$ & $29 \%$ & $52 \%$ & $18 \%$ \\
täisminevik & $62 \%$ & $29 \%$ & $9 \%$ & $51 \%$ & $23 \%$ & $27 \%$ \\
enneminevik & $2 \%$ & $12 \%$ & $86 \%$ & $24 \%$ & $23 \%$ & $52 \%$ \\
\hline
\end{tabular}

Sagedustabelis kokku võetud tulemuste järgi eestlaste rühmast suurim hulk on lünka valinud täismineviku: $62 \%$ täpselt sobivana ja $29 \%$ samuti sobivana. Samuti sobivaks on $43 \%$ märkinud ka lihtmineviku. Kõige ebasobivamaks on eestlased pidanud ennemineviku ajavormi ( $86 \%$ vastanutest). Vene rühmast üle poole (51\%) on samuti valinud täpselt sobivaks täismineviku, kuid kõige ebasobivamaks on $65 \%$ vastanutest märkinud oleviku. Üle poole (52\%) rühmast on lihtminevikku samuti sobivaks pidanud. Kahe rühma võrdlusest ilmneb, et üle poole kummagi rühma keelejuhtidest peab lausesse täpselt sobivaks täisminevikku ning umbes pool samuti sobivaks lihtminevikku. Mittesobiva ajavormi hindamisel lähevad arvamused lahku: enamik eestlastest on valinud ennemineviku, kuid venelaste rühmast suurem osa peab mittesobivaks olevikku. Statistiliselt olulist erinevust ei ole ainult lihtmineviku $(\mathrm{p}=\mathrm{o}, 3)$ sobivuse hindamisel.

Valikute põhjenduseks toodud seletused aitavad mõista erinevuste põhjuseid. Oma vastuseid põhjendanud eestlastest kolm on viidanud keelevaistule: "Põhjendada ei oska, keelevaist ütleb, et nii on.” Kõik neist on täpselt sobivaks pidanud lihtminevikku.

Suurem osa põhjendusi kirjutanutest on väitnud, et a) lause on olevikus (3 keelejuhti) ning valinud täpselt sobivaks oleviku või täismineviku, b) lause on minevikus (2 keelejuhti) ning valinud täpselt sobivaks täismineviku, c) lause võib olla nii olevikus kui ka minevikus (3 keelejuhti) ning valinud sobivaks nii oleviku, lihtmineviku kui ka täismineviku. Kaks vastajat on valiku teinud selle tõttu, et sõna "siis" viitab ühele vastajale liht- ning teisele täismineviku kasutamise vajadusele. Kaks vastajat on seletanud grammatiliste kategooriate abil: "Jutustaja kõneleb olevikus minevikulisest sündmusest.” Üks neist on täpselt sobivaks märkinud oleviku ja teine täismineviku. Kolm keelejuhti on tuge leidnud lause sisu oletatavast taustainfost: ajavormi valik oleneb sellest, kui vana kõneleja on, kas ta veel käib praegugi looduses või käis väiksena, ning sellest, kas vanavanemad on veel elus või juba surnud. Täpselt sobivaks on märgitud lihtminevik ning samuti sobivaks olevik ja täisminevik.

Vene keelejuhtidest kaheksa on oma valikut põhjendanud sellega, et lause on minevikus, ja valinud kas liht- või täismineviku. Kolm keelejuhti on kirjutanud, et tegemist on ammu toimunud sündmustega ja valinud ennemineviku täpselt sobivaks ajavormiks. Neli vastajat on kirjutanud, et lause on olevikus ning kõik on valinud täpselt sobivaks oleviku, kuid kolm keelejuhti lisaks ka täismineviku. Kaks keelejuhti on märkinud, et ei saa aru, millest jutustaja räägib, ja on kõik ajavormid täpselt või samuti sobivaks märkinud (sama on teinud veel kolm vene keelejuhti, kes põhjendusi kirjutanud ei ole). 
Viis vene keelejuhti on kirjutanud pikemad seletused selle kohta, et kuna lause tegelane käis looduses pika aja jooksul, see oli tema korduv tegevus ning lauses ei täpsustata, millal see oli, siis on õige täisminevik. Lisaks on üks valinud täismineviku, kuid oma põhjenduses nimetab seda enneminevikuks. Siin on märgatav terminoloogiline segadus, kuid ilmutatakse arusaamist täisminevikust kui ajavormist, mis väljendab kestvat korduvat tegevust minevikus, mille kindlat ajakohta ei ole määratletud.

Hinnatav lause võimaldabki valida mitu ajavormi, sest lüngaga lausele eelnev tekstilõik on olevikus ja järgnev lihtminevikus. Eestlaste valikute põhjal on kõige mittesobivam ajavorm enneminevik. Valikuid ja põhjendusi koos analüüsides ilmneb, et osa eesti keelejuhtidest, kes on väitnud, et lause on olevikus, on sobivaks ajavormiks märkinud täismineviku. Võib järeldada, et seda ajavormi tajutakse olevikku väljendavana.

Vene keelejuhtide põhjendusi ja valikuid koos vaadeldes ilmneb arusaam, et liht- ja täismineviku ajavormid on hiljutisemas minevikus toimunud tegevuse kirjeldamiseks kui ennemineviku ajavorm. Täismineviku valinud keelejuhid kirjeldavad lauset kui minevikus korduvalt toimunud tegevuse kirjeldust, milles kindlat ajakohta märgitud ei ole. Mitmes keelejuhis on selline tekstilõik segadust tekitanud ja nad ei ole ühtegi ajavormi täpselt sobivaks märkinud.

\subsection{Kolmas Iõik}

Tuba oli umbne. Avasin aknad. Ma ei suutnud aru saada, miks ma need kinni panen / panin / olen pannud / olin pannud. Ööõhk oli külm ja värske.

Tabel 3. Eesti ja vene keelejuhtide valikute tulemused protsentidena

\begin{tabular}{|l|c|c|c|c|c|c|}
\hline \multirow{2}{*}{ Kolmas lõik } & \multicolumn{3}{|c|}{ Eesti keelejuhid } & \multicolumn{3}{c|}{ Vene keelejuhid } \\
\cline { 2 - 7 } & $\begin{array}{c}\text { täpselt } \\
\text { sobiv }\end{array}$ & $\begin{array}{c}\text { samuti } \\
\text { sobiv }\end{array}$ & ei sobi & $\begin{array}{c}\text { täpselt } \\
\text { sobiv }\end{array}$ & $\begin{array}{c}\text { samuti } \\
\text { sobiv }\end{array}$ & ei sobi \\
\hline olevik & $1 \%$ & $3 \%$ & $96 \%$ & $1 \%$ & $8 \%$ & $91 \%$ \\
lihtminevik & $29 \%$ & $52 \%$ & $19 \%$ & $60 \%$ & $31 \%$ & $9 \%$ \\
täisminevik & $1 \%$ & $24 \%$ & $74 \%$ & $21 \%$ & $27 \%$ & $52 \%$ \\
enneminevik & $86 \%$ & $12 \%$ & $2 \%$ & $30 \%$ & $34 \%$ & $36 \%$ \\
\hline
\end{tabular}

Tulemuste põhjal on eesti keelejuhid pidanud kõige sobivamaks ennemineviku ( $86 \%$ vastanutest) ja samuti sobivaks (52\% vastanutest) lihtmineviku ajavormi. Kõige mittesobivamaks peetakse oleviku (96\% vastanutest) ja täismineviku ajavormi (74\% vastanutest). Eestlased tajuvad kogu kirjeldatud olukorda minevikulisena ning olevikku ja olevikuga seotud täisminevikku on täpselt sobivaks pidanud ainult $1 \%$ vastanutest.

Vene keelejuhtidest $60 \%$ on pidanud täpselt sobivaks lihtminevikku, kuid enneminevikku vaid 30\% ja täisminevikku 21\%. Olevikku on ebasobivaks pidanud 91\% ja täisminevikku 52\% vastanutest. Enneminevikku peab mittesobivaks $36 \%$, seega umbes kolmandik vastanutest. Ka venelaste rühm tajub kogu kirjeldatud tegevust minevikulisena, kuid milline mineviku ajavorm sobiv on, selles jagunevad 
arvamused oluliselt hajusamalt kui eestlaste rühma puhul. Näiteks enneminevikku täpselt sobivaks, samuti sobivaks ja mittesobivaks peavad üsna ühesuurused hulgad keelejuhtidest (vastavalt 30\%, 34\% ja 36\%). Samuti sobivaks on märkinud lihtmineviku $31 \%$, täismineviku $27 \%$ ja ennemineviku $34 \%$, mis moodustavad ka umbes kolmandiku vastajatest iga valiku puhul. Seega võib järeldada, et vene keelejuhtidel selget seisukohta liitminevike kasutamise kohta ei ole. Huvipakkuv on, et nii suur hulk vene keelejuhtidest on ennemineviku mittesobivaks ajavormiks märkinud. Kui lihtminevikku on pidanud mittesobivaks $9 \%$ vastanutest, siis enneminevikku neli korda rohkem - 36\% vastanutest. Liht- ja enneminevikku täisminevikule ei vastandata. Statistiliselt ei ole kahe rühma vahel olulist erinevust ainult oleviku $(\mathrm{p}=0,419)$ ajavormi sobivuse hindamisel.

Põhjendustes on kaks eesti keelejuhti kirjutanud, et lähtuvad oma keelevaistust. Suurem enamik (12 vastanutest) märgib, et tegevus toimus minevikus. Kuus nendest on täpselt sobivaks märkinud ennemineviku ja viis on valinud täpselt sobivaks nii enne- kui ka lihtmineviku. Üks keelejuht märgib kindlalt, et õige on lihtminevik, ning selle ka valinud. Üks vastaja põhjendab liht- ja ennemineviku valimist sellega, et tegemist on lõpetatud tegevusega, teine aga, et tegemist on lõpetamata tegevusega. Ajavormi valikul ei ilmne eestlaste põhjendustes üldiselt mingit selget seost tegevuse lõpetatuse või lõpetamatusega: kõikides mineviku ajavormides väljendavad verbid osa vastajate arvates kord lõpetamata, kord lõpetatud tegevust.

Vene keelejuhtidest seitse märgib, et on vaja minevikku. Kuuel neist on üks valikutest lihtminevik ja ühel ainult enneminevik. Kaks on täpselt sobivaks pidanud nii liht- kui enneminevikku ja üks keelejuht peab täpselt sobivaks kõiki mineviku ajavorme. Kaks üliõpilast on viidanud tegevuste järjekorrale, et põhjendada ennemineviku valikut: "Ta pani kinni enne, kui uuesti avas. Tegevus on enneminevikus." Mõlemad neist on ennemineviku ka valinud ja üks lisab, et lihtminevik sobib samuti. Ühe tegevuse eelnemisest teisele on kirjutanud veel kolm keelejuhti, kuid nad ei ole kasutanud sõna "enneminevik", vaid põhjendanud oma valikut: "Aknad olid enne kinni pandud, kui tuba saab umbseks." Samas on kaks neist täpselt sobivana valinudki ennemineviku, kuid üks täismineviku.

Põhjendustes on lähtutud ka teksti tüübist ja lauseehitusest. Teksti peetakse jutustuseks (3 keelejuhti) ja sellest lähtuvalt on valitud kahel juhul lihtminevik ja ühel juhul täisminevik. Jutustus on tavaliselt lihtminevikus, täismineviku valik on oletatavasti tehtud sellepärast, et akende sulgemist on mõistetud varasema tegevusena kui ülejäänud tegevusi. Üks keelejuht on lähtunud lauseehitusest ja märgib: "Kui lauset ei tohi muuta, siis sobib ainult "panin"." Siin on ilmselt silmas peetud, et liitminevike puhul ei tohiks verbi pöördeline vorm ja partitsiip kõrvuti olla, vaid pöördeline vorm peaks olema lauses aluse järel.

Mineviku ajavormi määramisel on kolm keelejuhti püüdnud otsustada, kas tegevus on lõpetatud, kas see kordub ja kas on kestev. Nii märgivad kaks neist, et ei saa aru, kas räägitakse ühekordsest või pidevast tegevusest ning märkinud täpselt sobivaks lihtmineviku ja samuti sobivaks kõik teised ajavormid. Keelejuht, kes on otsustanud, et tegevus on lõpetatud, peab täpselt sobivaks lihtminevikku. Niisiis mõistab ta lihtminevikku kui lõpetatud tegevust väljendavat ajavormi.

Eesti keelejuhid on pidanud sellesse lausesse kõige paremini sobivaks enneminevikku ja kuna põhjendustest ei selgu, kuidas see valik tehtud on, võibki oletada, et peamiselt on nad teinud teadvustamata valikuid. Vene keelejuhtide valiku- 
mehhanism on keerulisem: nad on lähtunud esiteks sellest, et lauses kirjeldatud tegevus on minevikus, kuid täpselt sobiva ajavormi valikul on tehtud erinevaid otsuseid. Osa on analüüsinud sündmuste toimumise järjekorda ja hinnanud enneminevikku täpselt sobivaks. Osa on lähtunud teksti tüübist ning lauseehitusest ja osa keelejuhte on proovinud hinnata tegevuse lõpetatust, korduvust ja järjepidevust. Nende kriteeriumide järgi on sobivaks hinnatud ka kõiki teisi ajavorme.

\subsection{Neljas lõik}

Mis on teis muutunud?

Me jääme / jäime / oleme jäänud / olime jäänud nendeks, kes me oleme, me ei aja nina püsti. Meie ei pea end staarideks.

Tabel 4. Eesti ja vene keelejuhtide valikute tulemused protsentidena

\begin{tabular}{|l|c|c|c|c|c|c|}
\hline \multirow{2}{*}{ Neljas lõik } & \multicolumn{3}{|c|}{ Eesti keelejuhid } & \multicolumn{3}{c|}{ Vene keelejuhid } \\
\cline { 2 - 7 } & $\begin{array}{c}\text { täpselt } \\
\text { sobiv }\end{array}$ & $\begin{array}{c}\text { samuti } \\
\text { sobiv }\end{array}$ & ei sobi & $\begin{array}{c}\text { täpselt } \\
\text { sobiv }\end{array}$ & $\begin{array}{c}\text { samuti } \\
\text { sobiv }\end{array}$ & ei sobi \\
\hline olevik & $51 \%$ & $29 \%$ & $20 \%$ & $60 \%$ & $16 \%$ & $23 \%$ \\
lihtminevik & $4 \%$ & $24 \%$ & $72 \%$ & $27 \%$ & $28 \%$ & $46 \%$ \\
täisminevik & $66 \%$ & $29 \%$ & $5 \%$ & $33 \%$ & $34 \%$ & $33 \%$ \\
enneminevik & - & $7 \%$ & $93 \%$ & $7 \%$ & $11 \%$ & $82 \%$ \\
\hline
\end{tabular}

Eestlased peavad selle lause lünka kõige sobivamaks verbi ajavormiks täisminevikku - 66\% vastanutest on seda täpselt sobivaks ja $29 \%$ samuti sobivaks hinnanud. Ainult $5 \%$ on selle mittesobivaks märkinud. Natuke üle poole (51\%) vastanutest peab täpselt sobivaks ka olevikku. Kõige suurem hulk peab mittesobivaks enneminevikku (93\% vastanutest) ning ligi kolm neljandikku (72\%) vastanutest peab mittesobivaks lihtminevikku. Niisiis peetakse lauset olevikuga seotuks.

Vene keelejuhtidest $60 \%$ on valinud täpselt sobivaks ajavormiks oleviku. Täismineviku või lihtmineviku täpselt sobivaks märkinute hulk on suhteliselt sarnane: vastavalt $33 \%$ ja $27 \%$. Täismineviku sobivust hinnates on vene keelejuhtide rühm jagunenud kolmeks võrdseks osaks: $33 \%$ peab seda täpselt sobivaks, $34 \%$ samuti sobivaks ja 33\% mittesobivaks. Sellest järeldub, et keelejuhtide arvates ei sobi olevikulises lauses täisminevikku kasutada, sest see on minevikku väljendav ajavorm. Kõige mittesobivamaks peetakse enneminevikku ( $82 \%$ vastanutest). Statistiliselt olulist erinevust ei ole rühmade vahel oleviku $(p=0,12)$ ajavormi sobivuse hindamisel.

Põhjendustes kirjutab seitse eesti keelejuhti, et lause on olevikus, ja on märkinud sobivaks ajavormiks oleviku või oleviku ja täismineviku. Üks neist põhjendab: “"Oleme jäänud" on halvem stiililiselt, täisminevik ei sobi, lause teine pool on olevikus." Selle keelejuhi arvates määrab lause ajavormi valiku järgnev tekst, mitte eelnev tekst. Täismineviku ajavorm tundub talle stiililiselt markeeritum kui olevik ja selle tõttu on ta märkinud täpselt sobivaks oleviku ajavormi.

Üks keelejuht on kirjutanud, et lause on minevikus ja tegevus lõpetatud ning märkinud täismineviku täpselt sobivaks ning lihtmineviku samuti sobivaks. Kaks 
keelejuhti on väitnud, et lauset võib mõista mitut moodi, ajavormi valik oleneb sellest, kas tegu on lubaduse või juba faktiga. Üks neist on täpselt sobivaks märkinud oleviku ja täismineviku ning teine täismineviku, kuid oleviku ja lihtmineviku valinud samuti sobivateks ajavormideks.

Vene keelejuhtidest kaksteist peab lauset olevikuliseks ning ongi valinud täpselt sobiva ajavormina oleviku, kolm neist on ka täismineviku valinud. Põhjendustena tuuakse välja, et see on kestev protsess ja et lõigu teised verbid on ka olevikus. Üks keelejuht arutleb, et seda, et intervjueeritavad ei ole muutunud, võib võtta nii tuleviku kui olevikuna.

Need neli keelejuhti, kes arvavad, et lause on minevikus, põhjendavad, et tegevus toimus mitte ammu minevikus ning on valinud lihtmineviku. Niisiis väljendab lihtminevik nende arvates hiljuti toimunud tegevust. Üks täismineviku valinu põhjendab, et lauses konstateeritakse fakti. Täisminevik väljendab tema arvates juba aset leidnud tõsiasja.

Üks keelejuht on valinud täpselt sobivateks liht- ja täismineviku, sest lõigu "esimesel poolel kirjutasime seda, mis oli, teisel poolel, mis on". Ta on tähele pannud, et küsimus on minevikus ja vastuse verbid olevikus, kuid täisminevikulisele küsimusele võib tema arvates vastata siiski lihtminevikus oleva lausega. Üks keelejuht on märkinud kõik ajavormid samuti sobivateks, sest tema arvates ei ole teada, kas tegevus kestab või on juba lõppenud. Täpselt sobivat ajavormi ta valinud ei ole.

Selle lõigu ajavormi hindamisel ilmneb selgesti vene keelejuhtide ebakindlus täismineviku ajavormi kasutamise suhtes. Eesti keelejuhid on täisminevikku kõige sobivamaks pidanud, kuid kolmandik vene keelejuhtidest on selle mittesobivaks märkinud. Eestlased seostavad täisminevikku olevikuga: nimetavad lauset olevikus olevaks ja valivad täpselt sobivaks ajavormiks täismineviku. Vene keelejuhtidest vähemalt kolmandiku arvates täisminevikul mingit seost olevikuga ei ole. Nii eesti kui vene keelejuhid on märkinud, et täismineviku ajavormiga konstateeritakse tõsiasja.

Olevik väljendab nii eesti kui vene keelejuhtide arvates praegu kestvat protsessi. Oleviku ajavormis verb võib väljendada ka tulevikku: "jääme nendeks, kes oleme" on lubadus tulevikuks.

\subsection{Viies lõik}

Olen endise loomaarsti poeg, vaatan sellele teemale vähe teise kandi pealt. Viin / viisin / olen viinud / olin viinud hulkuvaid koeri ja kasse vaktsineerimisele, kui on tasuta kampaaniaid ja muidu ka.

Tabel 5. Eesti ja vene keelejuhtide valikute tulemused protsentidena

\begin{tabular}{|l|c|c|c|c|c|c|}
\hline \multirow{2}{*}{ Viies lõik } & \multicolumn{3}{|c|}{ Eesti keelejuhid } & \multicolumn{3}{c|}{ Vene keelejuhid } \\
\cline { 2 - 7 } & $\begin{array}{c}\text { täpselt } \\
\text { sobiv }\end{array}$ & $\begin{array}{c}\text { samuti } \\
\text { sobiv }\end{array}$ & ei sobi & $\begin{array}{c}\text { täpselt } \\
\text { sobiv }\end{array}$ & $\begin{array}{c}\text { samuti } \\
\text { sobiv }\end{array}$ & ei sobi \\
\hline olevik & $57 \%$ & $29 \%$ & $14 \%$ & $77 \%$ & $8 \%$ & $15 \%$ \\
lihtminevik & $3 \%$ & $23 \%$ & $74 \%$ & $9 \%$ & $28 \%$ & $63 \%$ \\
täisminevik & $66 \%$ & $28 \%$ & $6 \%$ & $22 \%$ & $28 \%$ & $49 \%$ \\
enneminevik & - & $4 \%$ & $96 \%$ & $6 \%$ & $18 \%$ & $76 \%$ \\
\hline
\end{tabular}


Eesti keelejuhtide valikud on langenud kahe ajavormi, täismineviku (66\% vastajatest) ja oleviku (57\% vastajatest) kasuks. Enneminevikku peab mittesobivaks $96 \%$ keelejuhtidest ning lihtminevikku ligi kolmveerand, s.o $74 \%$ vastanutest. Niisiis peetakse lauset olevikuks või olevikuga tihedalt seotuks.

Vene keelejuhtidest $77 \%$ on valinud oleviku ajavormi, seega peetakse lauset selgelt olevikuliseks. Kõige suurem osa keelejuhtidest (76\%) peab enneminevikku mittesobivaks. Lihtminevikku peab mittesobivaks samuti üle poole (63\%) ja täisminevikku ligi pooled (49\%) vastanutest. Siit ilmneb, et täisminevik väljendab vene keelejuhtide meelest minevikus toimunud tegevusi, seost olevikuga ei mõista vaid osa rühmast. Statistiliselt olulist erinevust ei ole rühmade vahel lihtmineviku ( $\mathrm{p}=$ o,168) ajavormi sobivuse hindamisel.

Selle lause ajavormi valikut on põhjendanud üksteist eesti keelejuhti. Kaks lähtub keelevaistust või loogikast (nii on loogiline). Kolm on kirjutanud, et laused on olevikus ja üks põhjendanud, et lause teine pool on olevikus. Põhjendustes olevikust kirjutanud on valinud täismineviku ja samuti sobivana oleviku. Üks täismineviku valinu põhjendab seda asjaoluga, et tegevus on lõpetatud. Viis keelejuhti on kirjutanud, et sobib kaks ajavormi. Nad on valinud täismineviku ja oleviku ja põhjendanud, et ei ole teada, kas kirjeldatud tegevust tehakse siiani, sest tegevus pole lõppenud, tegevus on siiani toimiv ning et vorm on lause teises pooles annab võimaluse kahte vormi kasutada.

Vene keelejuhtidest kuusteist on põhjendanud, et lause on olevikus. Neist kaks on lisaks samuti sobivaks pidanud täisminevikku. Verbivorm on annab vihje, et tegemist on olevikuga (2 keelejuhti), lõigu teised verbid on olevikus (4 keelejuhti), tegevus on korduv (3 keelejuhti), jutustaja teeb seda alati (3 keelejuhti). Ühes pikemas põhjenduses väidetakse, et tegevus toimub praegu ja tulevikus, minevikuga mingit seost ei ole ja kuna olen viinud väljendab lõpetatud tegevust, siis see ka ei sobi.

Nii olevik kui minevik on täpselt sobivad kahe keelejuhi meelest, sest lause tegelane ei räägi konkreetsest juhust, tegevus on korratav. Lisaks on kaks keelejuhti kirjutanud põhjendused mineviku ajavormide valiku kohta: a) "Viisin - ta on seda teinud ja enam ei tee. Olen viinud - on viinud ja teeb seda ka praegu.” Täpselt sobivaks on üks keelejuht märkinud liht- ja täismineviku. Siin on väljendatud arusaamist liht- ja täismineviku erinevusest ning täisminevik seostatakse olevikuga. b) "Ennemineviku variant ei sobi, sest tuleb välja, et enam ta sellega ei tegele," kirjutab üliõpilane ja on samuti sobivaks märkinud oleviku ja liht- ning täismineviku ajavormid. Täpselt sobivat ajavormi keelejuht märkinud ei olegi. Põhjenduses on väljendatud arusaamist, et enneminevik on täielikult lõpetatud tegevus.

Eesti keelejuhtide verbi ajavormi valikud sarnanevad II ja IV lause valikutega ning neid peetakse oleviku ajavormis või olevikuga tihedalt seotuks olevaks. Vene keelejuhtide valikud II ja IV lause verbi ajavormi valikutega ei sarnane. Teise lõigu lauset on suuremas osas põhjendustest nimetatud minevikuliseks, kuid neljanda ja viienda lõigu lauseid olevikuliseks. Siiski on täisminevikku II ja IV lauses mittesobivaks pidanud umbes kolmandik ja V lauses ligi pool vene keelejuhtidest. Vene keelejuhid on täismineviku ajavormi hindamisel lähtunud teistest kriteeriumidest kui eesti keelejuhid. 


\section{Mõne keelejuhi arutluskäigud}

Nagu eespool öeldud, on 23 keelejuhti kirjutanud põhjendusi kõikide lausete verbi ajavormi valiku kohta. Kõikide keelejuhtide põhjenduste puhul ei saa täiesti kindel olla nende oskuses kasutada terminoloogiat (näiteks on vene keelejuht V166 kirjutanud, et olen käinud on enneminevik). Mõnede keelejuhtide puhul on osa põhjendusi nii napid, et nende järgi ei saa täielikku ülevaadet nende arutluse käigust. Siinkohal on tutvustatud selgelt väljendatud mõttekäike viielt keelejuhilt, kes on kirjutanud ajavormide tähendusest ja valikute tegemise protsessist.

Eesti keelejuht E92 on põhjendustes kirjutanud, et ajavormide valikud sõltuvad sellest, kuidas mõista lauses väljendatud tegevust. Ta on arvamusel, et liht- ja enneminevik väljendavad lõpetatud tegevust. Keelejuht E99 lähtub ainult tegevuse lõpetatusest. Tema arvates väljendavad liht-ja täisminevik lõpetatud ja enneminevik lõpetamata tegevust.

Vene keelejuhid V163 ja V170 on lähtunud lausete sisust ja tegevuste järjekorrast ning nad on teinud kõik valikud eestlastega sarnaselt. Enneminevik väljendab lihtminevikulisele tegevusele eelnenud tegevust, täisminevik väljendab pikaajalist praeguseni toimuvat tegevust, lihtminevik väljendab lõpetatud tegevust ning oleviku ajavorm väljendab nii olevikku kui tulevikku. Keelejuht V169 on samuti enneminevikku põhjendanud kui lihtminevikulisele tegevusele eelnevat tegevust, kuid täisminevikku peab ta lõpetatud tegevuseks, millel olevikuga seost ei ole. Kõige paremini väljendab tema arusaamist ajavormide vahekorrast II lause põhjendus, milles on kirjutatud, et olevikku kasutame siis, kui midagi tehti minevikus ja tehakse kogu aeg; lihtmineviku ajavorm väljendab eile toimunud tegevust ja enneminevikuline sündmus toimus üks kord minevikus.

\section{Kokkuvõte}

Lausete ajavormi hinnangutele on kirjutatud kokku 185 põhjendust. Need võib jagada kolmeks: 1) hinnangut põhjendatakse keelevaistuga (2 juhul vene ja 16 juhul eesti keelejuhid); 2) viidatakse reeglile ( 88 juhul vene ja 51 juhul eesti keelejuhid) ning 3) viidatakse lause sisule (19 juhul vene ja 10 juhul eesti keelejuhid). Reeglitele viitamisel kasutasid vene keelejuhid 79 juhul ja eesti keelejuhid 43 juhul keeleteaduslikku metakeelt, kuid ülejäänud juhtudel kasutatakse oma sõnu ja ei saa päris kindel olla, kas lähtuti normatiivsest reeglist või teadvustamatust teadmisest.

Tulemustest järeldub, et venekeelsete keelejuhtide eesti keele oskuse ja keeleteadmiste tase on erinev. Selle tunnistuseks on statistiliselt oluline hajuvus ajavormi valikutes ning ajavormide valiku põhjendamise ebaühtlane oskus. Oma valikuid on põhjendanud ainult üks neljandik keelejuhtidest, sellest võib järeldada, et teistele on see raskusi valmistanud. Põhjendusi kirjutanute hulgas on samuti keelejuhte, kes on keeleteaduslikku terminoloogiat valesti kasutanud. Kõikidest põhjendusi kirjutanud keelejuhtidest on teadlikke valikuid teinud ja neid järjekindlalt põhjendada osanud 23 üliõpilast, neist 16 vene ja 7 eesti keelejuhti. Seitsmest eesti keelejuhist kaks on kirjutanud, et juhinduvad oma keelevaistust. Võrreldes eesti keelejuhtidega on vene keelejuhid oma valikuid rohkem põhjendanud. Seda on teinud suurem hulk vastanutest (16 keelejuhti on põhjendanud kõiki oma valikuid) ja põhjendused on pikemalt kirjutatud. Kui põhjenduse reale on kirjutatud üks sõna, näiteks ainult 
"olevik" või "minevik", siis on keeruline oletada, kas sellega kinnitatakse sõnaliselt ajavormi valikut või on silmas peetud, et valik on tehtud selle tõttu, et lause tegevust väljendab nimetatud ajavorm. (Eelpool liigitasin sellised põhjendused oma sõnadega reeglile viitamiseks.) Kokku 18 keelejuhti on kirjutanud terminoloogiliselt täpselt ning on ajavorme hinnanud nii, nagu põhjendustes kirjutatud. Mitmed ilmselt vähema keeleoskusega üliõpilaste kirjutatud põhjendused ei vasta tegelikele valikutele ning nad ei erista selgelt täis- ja enneminevikku, s.t enneminevikku on täisminevikuks nimetatud ja vastupidi.

Eesti keelejuhtide põhjendustest selgub, et liht- ja enneminevikku peetakse ajavormideks, mis väljendavad minevikus toimunud tegevusi, ja täisminevikku tugevalt olevikuga seotuks või peaaegu oleviku ajavormiks. Sellest annab tunnistust asjaolu, et mitmetes põhjendustes on lauset minevikuliseks nimetatud ning valitud täpselt sobivaks liht- või enneminevik, kuid lause tegevust olevikuliseks nimetanud on täpselt sobivaks märkinud täismineviku ajavormi. Siinse põhjal võib oletada, et eestlased tajuvad täisminevikku aspekti väljendusena, sest ajaliselt seostub täismineviku ajavorm neile olevikuga.

Vene keelejuhid eristavad olevikku ja lihtminevikku: nad on osanud nende vormide sobivust lausesse põhjendada ja valinud ka tegelikult põhjenduses nimetatud vormi. Täismineviku seotust olevikuga vene keelejuhid erinevalt eestlastest üldiselt ei mõista. Täisminevik seostub neile faktide konstateerimise, tegevuse korduvuse ja lõpetatusega. Siiski on nimetatud tegevuse jätkuvust praegu ja võimalik, et tulevikus.

Ennemineviku valiku suhtes tundub vene keelejuhtidel olevat suuri kõhklusi, sest kui eestlaste valikud näitavad kindlalt, kas enneminevik on mingisse lausesse sobiv või mittesobiv ajavorm, siis vene keelejuhtide valikud on näiteks esimeses ja kolmandas lõigus, kus enamik eesti keelejuhte on ennemineviku täpselt sobivaks märkinud, valikud langenud kas lihtmineviku kasuks või jagunenud üsna ühtlaselt kõigi kolme mineviku ajavormi vahel. Siiski saadakse hästi aru, millisesse lausesse enneminevik ei sobi.

Statistiliste testide põhjal võib samuti väita, et kui hinnata on vaja mineviku ajavormi sobivust, siis olulised erinevused on eesti ja vene rühma vahel täis- ja ennemineviku, kuid mitte lihtmineviku valikutes. Eesti keelejuhid on valinud liitminevike ajavorme sagedamini ja üksmeelsemalt, vene rühmasisene hajuvus on palju suurem, mis tekitabki statistiliselt olulise erinevuse. Siiski hindab vene keelejuhtidest umbes üks kolmandik liitmineviku ajavormide sobivust lausesse eestlastega ühesuguselt. Seega ei saa selle ülesande tulemuste põhjal väita, et lihtminevik on liitmineviku ajavorme eesti keelest välja tõrjumas.

\section{Viidatud kirjandus}

Birdsong, David 1989. Metalinguistic Perfomance and Interlinguistic Competence. Berlin: Springer.

Chomsky, Noam 1980. Rules and Representations. Oxford: Basil Blackwell Publisher Ltd.

Ellis, Rod 2004. The definition and measurement of L2 explicit knowledge. - Language Learning, 54, 2, 227-275. doi:10.1111/j.1467-9922.2004.00255.X

Ellis, Rod 2005. Measuring implicit and explicit knowledge of a second language: A psychometric study. - Studies in Second Language Acquisition, 27, 2, 141-172. doi:10.1017/ $\underline{\text { S0272263105050096 }}$ 
Ellis, Rod; Barkhuizen, Gary 2006. Analysing Learner Language. Oxford: Oxford University Press.

Ellis, Rod 2008. Investigating grammatical difficulty in second language learning: Implications for second language acquisition research and language testing. - International Journal of Applied Linguistics, 18, 1, 4-22. doi:10.1111/j.1473-4192.2008.00184.X

Erelt, Mati 2006. Lause õigekeelsus. Tartu.

Külmoja jt = Кюльмоя, Ирина; Вайгла, Эда; Солль, Майе 2003. Краткий справочник по контрастивной грамматике эстонского и русского языков. Тарту: Tartu Ülikooli Kirjastus.

Külmoja, Irina 2007. Taksise kategooriast vene ja eesti keeles. - Raili Pool (Toim.). Emakeel ja teised keeled V. Tartu Ülikooli eesti keele (võõrkeelena) õppetooli toimetised, 6. Tartu: Tartu Ülikooli Kirjastus, 78-88.

Leemets, Tiina 200o. Mitmeplaaniline minevik. - Keelenõuanne soovitab 2. Tallinn: Eesti Keele Sihtasutus, 87-90.

Macaro, Ernesto 2006. Strategies for learning and language use: Revising the theoretical framework. - Modern Language Journal, 90, 3, 320-332. doi:10.1111/j.1540-4781.2006.00425.x

Mackey, Alison; Susan M. Gass 2005. Second Language Research: Methodology and Design. London: Lawrence Erlbaum Associates.

Metslang, Helle 1993. Verbitarind ajatähendust väljendamas. - Virittäjä, 2, 203-221.

Metslang Helle 1991. Ajast ja tema vormist verbitarindeis. - Keel ja Kirjandus, 3, 163-168.

Metslang, Helle 2006. Predikaat ajastut kogemas. - Keel ja Kirjandus, 9, 714-727.

Pool, Raili 2006. Täis- ja osasihitise kasutamisest eesti keelt teise keelena õppijate pilgu läbi. - Eesti Rakenduslingvistika Ühingu aastaraamat, 2, 185-202.

Pool, Raili 2007. Eesti keele teise keelena omandamise seaduspärasusi täis- ja osasihitise näitel. Dissertationes philologiae estonicae Universitatis Tartuensis, 19. Tartu: Tartu Ülikooli Kirjastus.

Pool, Raili; Vaimann, Elle 2005. Vead kõrgtasemel eesti keele kõnelejate kirjalikus keelekasutuses. - Eesti Rakenduslingvistika Ühingu aastaraamat, 1, 115-137.

Saari, Henn 2004. Keelehääling: Eesti Raadio "Keeleminutid" 1975-1999. Sirje Mäearu (Koost.). Eesti Keele Instituut. Tallinn: Eesti Keele Sihtasutus.

Seliger, Herbert W.; Shohamy, Elana 1989. Second Language Research Methods. Oxford: Oxford University Press.

Diana Maisla (Tartu Ülikooli Pärnu kolledž) uurimisvaldkond on eesti keele kui teise keele omandamine ja kasutus.

diana.maisla@ut.ee 


\section{HOW ESTONIAN LANGUAGE LEARNERS AND USERS JUDGE TENSE ACCEPTABILITY IN SENTENCES}

\section{Diana Maisla}

Pärnu College, University of Tartu

This paper presents results of an acceptability judgement test of verb tenses in five different sentences. The test was carried out in the Estonian language. The Estonian tense system consists of four tenses (present, past simple, present perfect, pluperfect). Two informant groups were tested - 100 native speakers of Estonian and 96 students with Russian as their mother tongue (who are learning Estonian as a second language). Informants had to judge the acceptability of tense usage in five sentences on the scale suits precisely / also suitable / does not suit. The informants also had to explain their decision.

The collected data was processed and results of statistical tests were used to elucidate differences between the two informant groups. Significant differences between the two groups became apparent in the choice between present perfect and pluperfect, but suitability of the present and past simple tense both groups had relatively similar results.

Argumentations explaining the given judgements can be divided into three groups: 1) explaining judgements by linguistic intuition; 2) reference to grammar rules; 3) reference to the content of a sentence. In comparison with native speakers, Russian-speaking informants justified their decisions in more detail and at greater length; also, more informants offered explanations. These argumentations and factual judgements enable drawing conclusions about informants' knowledge and understanding of when and how to use the Estonian tenses. The Estonianspeaking informants describe past simple and pluperfect as tenses which express events taking place in the past, while present perfect is described as a tense tightly connected with the present. The Russian-speaking informants distinguish between present and past simple tenses, i.e. they can judge acceptability of a tense form in a sentence, and also explain their judgement. However, they do not understand the connection between the present tense and the present perfect tense. For them the present perfect is associated with reporting facts, and with repeating, ceasing, or continuing an action.

Russian-speaking informants seemed hesitant about the use of pluperfect. While Estonian-speaking respondents clearly indicated whether or not the pluperfect was a suitable tense in a sentence, the Russian-speaking informants preferred the simple past tense or split their choices evenly between all past tenses.

According to statistical tests there is a significant difference between the groups when assessing acceptability of compound past tenses, but not in the case of the simple past tense. The Estonian-speaking informants are consistent when judging acceptability of compound past tenses; within the Russian-speaking group divergence was much wider and this affected the statistically significant difference. Hence, the results show that $30 \%$ of Russian-speaking informants judge acceptability of a compound tense the same way as do Estonian native speakers.

Keywords: Estonian as a second language, verb tenses, grammatical acceptability judgement test, introspection, Estonian 